\title{
FEATURE
}

\section{Use of Public Libraries by Immigrants}

\author{
Susan K. Burke
}

Susan K. Burke is Assistant Professor, School of Library and Information Studies, University of Oklahoma, Norman. Submitted for review October 5, 2006; revised and accepted for publication July 23, 2007.
Reference \& User Services Quarterly, vol. 48, no. 2 , pp. 164-174

(c) 2008 American Library Association. All rights reserved.

Permission granted to reproduce for nonprofit, educational use.
The United States has experienced increased immigration rates since 1990 and public libraries are faced with providing services to immigrants from a wide variety of cultural backgrounds. Which immigrants are the most likely to utilize public library services? This study uses data from the U.S. Current Population Survey from 2002 to compare households of immigrants from various world regions on the use of public libraries in the past month and the past year. Immigrant households' rates of library use are also compared to households of native-born U.S. citizens.

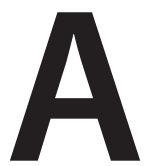
merican public libraries have a long history of service to the foreign-born. While today's immigrants have much in common in terms of library needs with immigrants from earlier periods, the demographic character of newcomers to this country has changed substantially. For example, one hundred years ago immigrants were predominately European. Today's immigrants are much more likely to be from Latin America and Asia. ${ }^{1}$ Immigration rates have increased since 1990. According to U.S. Census Bureau data, in 2000 immigrants were more than $11 \%$ of the U.S. population for the first time since 1930. ${ }^{2}$ By 2004 there were 34.2 million foreign-born residents in the United States, or 12\% of the population. ${ }^{3}$ In addition to immigrants themselves, the 2000 census showed that fully $20 \%$ of $\mathrm{K}-12$ students were children of immigrants. ${ }^{4}$ It is undeniable that these numbers of immigrants are having and will continue to have a significant impact on U.S. institutions such as public libraries.

How are public libraries serving such diverse populations? Materials in languages other than English, bilingual and bicultural staff members, literacy instruction, and English-as-a-secondlanguage courses are some of the more common strategies. In addition, libraries can partner with federal Americanization agencies. The U.S. Citizenship and Immigration Services has had vendor booths at American Library Association Annual Conferences to promote naturalization and citizenship materials for public libraries. Federal outreach to immigrants through public libraries dates back at least to the World War I era. ${ }^{5}$

\section{LIBRARY USE STUDIES}

There have been many studies on characteristics of public library users and nonusers. Lawrence White stated that at least fifty such studies have been conducted since the 1930s. Douglas Zweizig and Brenda Dervin focused on 
sixteen studies that they identified as truly comparable. ${ }^{6}$ In their analysis of these studies, Zweizig and Dervin concluded that $10-23.5 \%$ of U.S. adults use the public library at least once a month, and $21-64 \%$ at least once a year. ${ }^{7}$ Most of the studies examined demographic variables as predictors of library use. Of these, education level was consistently the strongest predictor. Socioeconomic variables such as income and occupation were weak predictors, and age was curvilinear (use increased with age to a certain point then decreased). Sex, race, and marital status were not important predictors. ${ }^{8}$ Judith Payne found that the presence of school-aged children and the education process were strong reasons for library use. ${ }^{9}$ Carol Kronus identified family size and county size as influential. ${ }^{10}$ Some researchers found nondemographic variables such as attitudes and habits were better predictors of library use than demographic variables. ${ }^{11}$

\section{LIBRARY USE BY IMMIGRANTS}

Studies have also been done on immigrants' use of public libraries. These generally focused on immigrants from specific geographic regions and located in particular areas of the United States. Most studies of immigrant library users concern Latino immigrants. While the professional literature contains a wide variety of articles detailing experiences of or suggestions for serving immigrant populations, only those providing numerical or statistical data are reviewed here.

Around 1990, Amado Padilla used a focus group to gather perceptions from Latino immigrants in East Palo Alto, California. Only four of the Latinos in the group had used a California library. Padilla did not state the total group size, so it is not possible to determine what proportion this represents. None of the Latinos had used a library in their native country. ${ }^{12}$

Susan Luevano-Molina did a qualitative study on fifty Latino, predominately Mexican, immigrants in Santa Ana, California in 1996. She found these immigrants to have high awareness of libraries in their home countries and in the United States, with half (48\%) having used non-U.S. libraries. About half (50\%) had also used a public library in Santa Ana. Even 33\% of undocumented immigrants in this study had valid library cards. Luevano-Molina reported that in Santa Ana the Latino community considered the library neutral ground where even undocumented immigrants can seek to improve themselves and obtain materials for their children. ${ }^{13}$ For respondents in this study, having school-aged children was the best predictor of library use. In a later book chapter, LuevanoMolina cites a report from the Institute for the Future from 1996 that states that Hispanics and Asians are California's heaviest public library users. ${ }^{14}$

Ninfa Trejo interviewed fifteen families in Arizona in 1996; ten were immigrant Latino families, three were Mexican Americans, and two were white families. In total, seventy-one family members, twenty-six of whom were adults, were interviewed. Only one person of the seventy-one had never used the library, and time since last use of the library ranged from zero to thirty years. The average length of time since last use of the library was two and a half years. All of the families stated that they used the public library, and half of the families had library cards. ${ }^{15}$

In 2000, the State Library of North Carolina commissioned a study on the library needs of Hispanics living in North Carolina. From 1,003 telephone interviews, they found that $26 \%$ of Hispanic respondents had used the public library at least monthly, with $40 \%$ reporting use in the past year. A regression analysis showed the most influential factors in library use were respondent's belief that he or she lived close to a library, those who rated their English-reading skills more highly, higher education, those that rated their English-speaking skills more highly, and those with children under eighteen years old. ${ }^{16}$

Frances Flythe found that, of seventy-one Hispanic immigrants in Durham County, North Carolina, 22\% had used the library at some time. ${ }^{17}$ In a 2002 study of Latino residents in Missouri, Beth Bala and Denice Adkins conducted forty-one door-to-door interviews and found that $22 \%$ of respondents had used the library in the past six months. ${ }^{18}$ In general, these studies found that barriers to public library use by Latino immigrants included cultural unfamiliarity with libraries, language barriers due partially to low education and literacy levels, mistrust of government agencies, scheduling conflicts, location-related issues, and cultural conflicts such as silence rules. ${ }^{19}$

Concerning library use by Asian immigrants, Sherry Su and Charles Conaway interviewed a sample of 180 elderly Chinese immigrants in the Los Angeles region in 1993. Nearly twothirds of these respondents (63.3\%) reported using the library at some time in the past year, and one-fifth (19.4\%) used the library more than monthly. The most common reasons for going to the library were to read materials and to borrow books..$^{20}$ Padilla found that Korean immigrants were more likely to view libraries as quiet study areas, not places to obtain books and other materials. He stated that Asian immigrants were accepting of "silence" in the library because it echoed cultural traditions from their home countries. ${ }^{21}$

In a multicultural study, Cheryl Metoyer-Duran studied the information-seeking behavior of ethno-linguistic community leaders in California in 1990. She analyzed interviews of 120 leaders from Latino, Chinese, Japanese, Korean, and American Indian communities. These leaders were a mix of immigrants and nonimmigrants, with most of the Chinese and Korean respondents born outside the U.S., more than half of the Latinos U.S.-born, and only three of the Japanese born abroad. In rating public libraries as an information source, Chinese (64\%) and Japanese (62\%) leaders were most likely to rate the library as very good or good (as opposed to average or poor). About half of Latinos (53\%) and Koreans (53\%) rated the public library as very good or good. As for visiting the public library in the last year, the majority of community 


\section{FEATURE}

leaders had done so: Chinese (83\%), Korean (79\%), Latino (79\%). Japanese leaders were much less likely than other groups to have visited the public library in the past year (33\%). ${ }^{22}$

The Urban Library Council surveyed 73 public libraries and found most of the recommendations in the literature for successfully serving immigrant patrons had been implemented. Their results showed that $93 \%$ of libraries surveyed had staff with multiple language skills, $89 \%$ had library brochures in multiple languages, $71 \%$ conducted staff training on providing multicultural customer service, and $66 \%$ had collections in ten or more languages. ${ }^{23}$

In summary, these studies establish a profile of general library users in the United States and include information on the library use of immigrants from Latin American and Asian countries. Little has been done on immigrants from other world regions, and the studies of Latin American immigrants predominately used small sample sizes and were limited to particular geographic regions in the United States. This paper will examine the library use of immigrants from many world regions who have settled in a variety of geographic regions in the United States.

\section{MODELS OF THOUGHT ON LIBRARY USE}

Much of the literature on immigrant library use is based upon a service model that focuses on what the library is doing or not doing to attract patrons. Research from this model informs librarians on how to make their libraries more welcoming, attract more patrons, and create more patron satisfaction with library materials and services. One aspect of the model is to make the library more appealing by reducing perceived barriers to use. Some barriers for immigrant patrons that were identified in the literature were lack of cultural sensitivity of library staff and library policies, language barriers, and inconvenient hours and locations. The other aspect of the service approach entails tailoring collections and services to identified needs in the patron community. By addressing barriers to public library use and targeting patron communities accurately, libraries may appeal to wider potential patron audiences.

In a panel presentation at the April 2007 Oklahoma Library Association Annual Conference, three librarians with extensive experience working with immigrant populations gave suggestions for making the library more welcoming and useful. ${ }^{24}$ The following is an outline of their comments combined with suggestions from the literature:

1. Collections and Programs

a. Have current (not outdated) collections of materials in immigrants' languages and on topics of interest to immigrant groups.

b. Create programs on areas of interest to new immigrants such as immigration law, citizenship, job searching, health, and literacy.

2. Staff and Library Atmosphere

a. Have bilingual/bicultural staff, volunteers, tutorials, computer classes, computer interfaces, library signage, and pamphlets.

b. Have a hospitable atmosphere with friendly, proactive staff that ask patrons if they need help and who are respectful of patrons' individuality rather than making assumptions on the basis of their perceived cultural background.

c. Provide cultural training for staff that particularly includes training on how to be respectful and polite across cultural boundaries; for example, do not touch patrons or call them by their first name because these acts of familiarity may be culturally insensitive.

3. Be in Touch with the Community

a. Do needs assessments and community analyses to gather information to guide collection and service decisions.

b. Promote the library through immigrant community centers, community leaders, religious institutions, social services centers, schools, and radio advertisements in other languages.

c. Perform outreach with bookmobiles, new branches, and accommodating hours.

This service model focuses on the library and implies that whether people use the library is a function of the library and its offerings. Most suggestions for how to increase the library's appeal to various populations are based on the notion that if they are offered the right combination of materials, programs, hours, and locations, people will choose to use the library.

Another model of library use examines factors of the individual that influence whether that person becomes a library user. This sociological model of library use examines a variety of social and demographic characteristics of patrons and determines which characteristics correlate with higher rates of library use. Reviewed studies identified socioeconomic factors such as education, income level, and occupation as linked to likelihood of library use. While sex, race, and marital status were not found to be important predictors, age was somewhat important, and family variables such as living with children and size of household were useful. ${ }^{25}$ Other research found that distance from the library and county size were related to library use. ${ }^{26}$ For immigrants, confidence in speaking and writing in English were also influential. ${ }^{27}$ Identifying the likely patron base in this manner is useful to libraries that are planning marketing and outreach efforts and library services and programs. In addition to identifying factors that correlate with higher library use, this model also addresses sociocultural aspects of individuals that may predispose them to not use the library. From the literature, for some immigrants these include cultural unfamiliarity with libraries, low education and literacy levels, and mistrust of government agencies.

Scott Nicholson refers to this model of library use as understanding information seeking in context. He states that each library user is situated in one or more contexts that affect their information needs and information seeking 
behavior. Most individuals belong to several communities, and their contexts can be known or unknown to library researchers. ${ }^{28}$

While the sociological model presents a fundamentally different view from the service model of factors affecting public library use, the models work together quite well. Some individuals will not be likely to become library users because of a variety of contexts in their backgrounds or circumstances, so no matter what the library does it is unlikely to attract these individuals. However, even those who are likely to be interested in using the library might become nonusers if their experience of the library is unpleasant for any of a number of reasons, or if they determine that the library does not have materials or services that fill their needs. It is therefore useful for libraries to be sensitive to the issues presented by both the service and the sociological models of library use.

This study is based on the sociological model and examines rates of public library use and factors that might affect those rates such as the context of user backgrounds and demographic information.

\section{METHOD}

This study uses federal data from the Current Population Survey (CPS) to examine library use. The following are the questions the study attempted to answer:

1. Do library usage rates vary between immigrants from different regions of the world, as represented by households of immigrants from these regions?

2. In the United States, are households of native-born residents more likely to report public library use than those of foreign-born residents?

3. What are some sociodemographic factors that affect rates of household public library use?

The CPS is a household sample survey that is conducted several months out of every year by the U.S. Bureau of the Census to collect labor force data. Other information is occasionally gathered by including supplemental questions. Data for the present study were collected with the CPS October 2002: School Enrollment/Library Use supplement. The sample universe for the CPS is the U.S. civilian noninstitutionalized population living in households. The sampling method is a multistage probability sample of households from all fifty states and the District of Columbia, and data are gathered using a series of structured, closed-ended questions. Households are selected, then data are gathered about all persons in the household. One person in the household becomes the "reference person" and answers questions for all members of the household if possible. The reference person must be fifteen years of age or older. Since households are chosen and not individuals or families, data are gathered about all household members no matter their relationships to each other. The October 2002 dataset contained 159,887 respondents that lived in 57,148 households. ${ }^{29}$

Some of the questions regularly asked by the CPS concern each individual in the household, such as the country in which a person was born, country in which each parent was born, education level, and other demographic information. Other questions are asked about the household, such as "Is there a telephone in the household?" All of the library use questions in this supplement were asked of the household, and not of individuals in the household. It is not possible to determine which individuals in a household used the public library in the past month, only whether anyone in the household used the library. For this study a household variable was created that specified the immigrant status of the household overall. Households were coded as consisting of U.S.-born persons, immigrants by world region of origin, or mixed. Households in which children of immigrants were under age 25 were coded to the immigrant region of the parents and not as mixed households, even though children of immigrants born in the U.S. are considered native-born Americans.
Immigrant households in which U.S.born children or other U.S.-born adults age 25 and older resided were classified as mixed households and not analyzed in this study. Households from mixed world regions, but not containing native-born Americans age 25 or over were coded to the world region of the reference person.

Native-born U.S. citizens who were born abroad were coded in the U.S.born household category. These individuals might, for example, include those born to military families stationed abroad, travelers, and others whose parents were abroad at the time of their birth. Respondents coded as being from "elsewhere" were eliminated from the analysis. Respondents from Australia, New Zealand, Fiji, and the Pacific Islands were also not analyzed because there were too few to make meaningful comparisons.

\section{STATISTICAL METHODS USED}

Two techniques of data comparison were used in the analysis. The main discussion compares percentages of different groups' use of the public library. Secondly, chi-square was used to determine whether the amount of difference between two groups was likely to have occurred from chance alone, or whether the difference was large enough to suggest an actual difference between groups. When the difference between groups is large enough to be unlikely to have happened by chance, that is referred to as statistically significant. The chi-squares in this analysis were conducted on the frequencies (actual numbers) and were calculated for $2 \times 2$ contingency tables at a .05 alpha level. Chi-square is sensitive to sample size, so this statistic could not be calculated for the native-born U.S. citizens because fifty thousand households were too many for the test to have meaning. Since the immigrant groups were represented by far fewer households, it was appropriate to conduct chi-square on differences between these groups. In the data analysis discussion, when it states that the difference between 


\section{FEATURE}

certain groups was significant, it is referring to the chi-square calculation between those groups showing statistical significance. Chi-square was used in the data analysis section on library use by immigrant groups, but it was not used in the section on additional demographic variables because the multilevel analyses resulted in smaller sample sizes per table cell. In addition, percentages were not calculated when sample size for a cell was twenty-five or fewer households.

\section{LIMITATIONS OF THE STUDY}

There are limitations to using available data. Researchers using available data are restricted to the questions asked by the original researchers. Questions often do not represent exactly what the current researcher wants to know. How the data were coded and entered is also under the control of the original researchers and may not be as useful for secondary analysis as it might have been if coded in a different manner. A specific limitation of the data in this study is that the library questions were asked at a household level. A more indepth picture of immigrant library use could have been established if the questions had been answered by individuals in the household. There were no qualitative data available for this study. As a result, only the general picture of library use is available, but not the type of individual reasoning that might have been available with additional qualitative data.

\section{DATA ANALYSIS}

Three questions were asked about general library use. "In the past month, that is since (month) (day), has any member of your household used a public library or bookmobile for any reason?" Respondents who answered "no" to the first question were then probed for additional affirmative responses with the following question, "How about to borrow materials, take a class, to use the computers or for activities for children?" Responses to these two questions were combined to get an overall figure for public library use in the past month. Respondents who answered "no" to these two questions were then asked, "Has anyone in your household used a public library or bookmobile in the past year, that is since October, 2001?" Answers to the library use questions were crosstabulated with the immigrant household variable to produce the following figures.

As can be seen in figure 1, respondents from some geographic regions were more likely to have used the public library in the past month than respondents from other regions. Differences between groups had a range of 21.5 percentage points from a low of $23.2 \%$ for European households to a high of $44.7 \%$ for South Asian households. Excluding these two outliers, all other households fell within 10 percentage points of each other, from Central American or Mexican households at $27.2 \%$ to Southeast Asian households at $37.3 \%$.

Not all of the differences between groups were large enough to be meaningful. Using the lowest (European) and highest (South Asian) library use as the comparison groups for calculation, the point where the chi-square test showed

a significant difference between groups divided them into low, middle, and high categories of library use in the past month as follows:

- Low use: Households classified as European, Central American or Mexican, Canadian or other North American, Caribbean, East European, and Middle Eastern

- Middle use: Households classified as African, U.S. native-born, East Asian

- High use: Households classified as South Asian, Southeast Asian, and South American

When calculating statistical significance, there was some overlap between groups in the middle category and groups in the lower and higher categories. For example, while the difference between Middle Eastern households in the lower use category and East Asian households in the middle category was not significant, the difference between Eastern European households and East Asian households was significant. From the middle to the upper levels, the difference between East Asian households and Southeast Asian was significant, but the differences between East Asian

Figure 1. Someone In Household Used Public Library In Past Month (Numbers In Percentages)

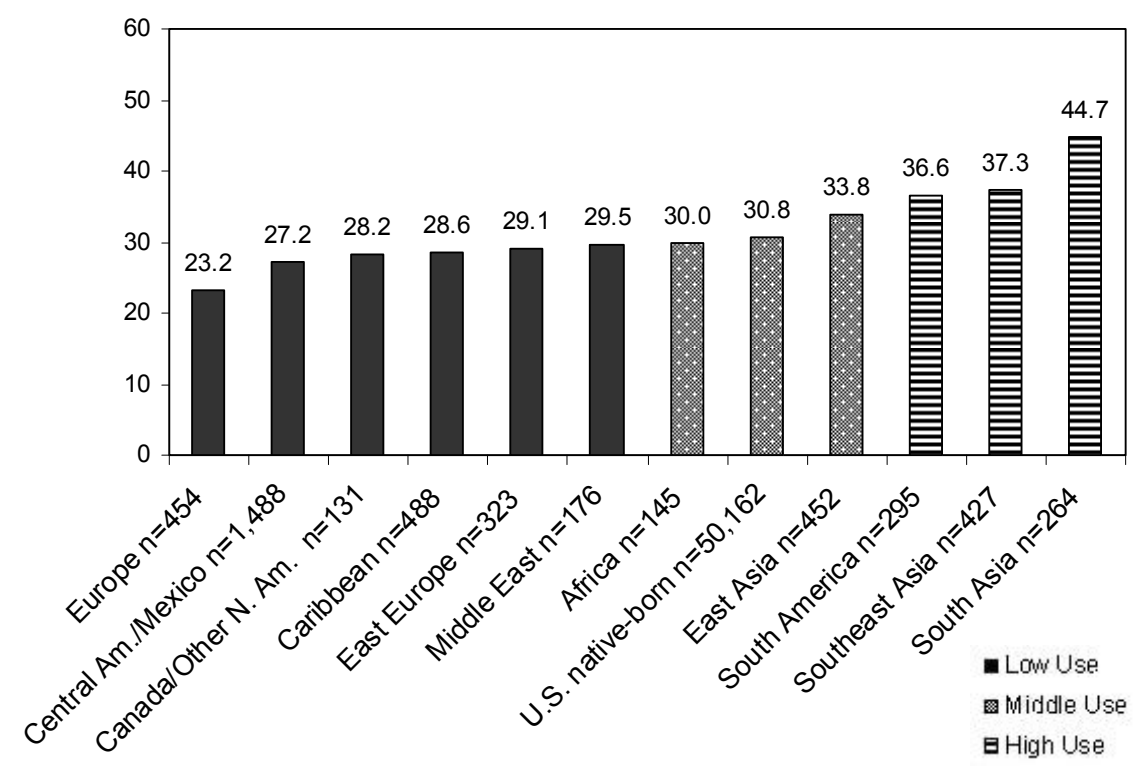


households to South American and African to South American households were not significant.

Figure 2 shows rates of public library use in the past year. Concerning this use, during the past year European households were once again the least likely to have used the library at $37.8 \%$. South Asian households were again the most likely library users at $57.9 \%$, a range of 20.1 percentage points. While rates of public library use for all households went up when comparing use in the past month to the past year, the placement by geographic region in low-, middle-, and high-use categories stayed the same for all groups except for Canadian or other North American, which jumped from the low-use to the high-use group. This suggests that the factors that affected decisions to use the public library remained consistent from a monthly to a yearly basis.

While the low-, middle-, and highuse group cutoffs in figures 1 and 2 were chosen on the basis of calculations of statistical significance, looking at the tables would suggest that a practical division might move the group boundaries slightly. This is particularly clear in figure 2, in which it seems that Middle East should be moved from the lower to the middle category and Canadian and other North American should be moved down from the upper to the middle category.

\section{SOCIODEMOGRAPHIC ANALYSIS}

In the literature, the needs of newly arrived immigrants differed from those of established immigrants. New immigrants need information on jobs, housing, literacy/ESL, and citizenship. As immigrants become more established, their library needs blend with those of U.S.-born patrons. Year of entry by world region indicates that there is quite a difference in the immigration patterns of people from different world regions. Table 1 shows, for example, that more than $75 \%$ of European immigrants arrived prior to 1989 , so patrons from that group will likely have fewer

Figure 2. Someone In Household Used Public Library In Past Year (Numbers In Percentages)

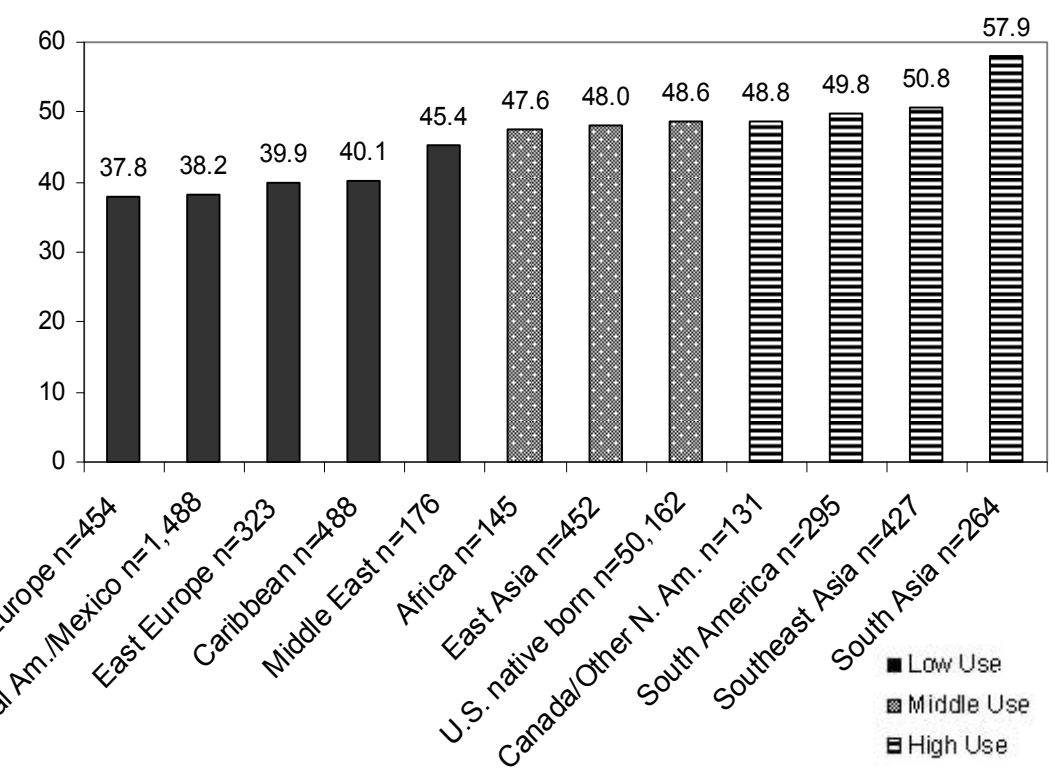

specialized library needs than other groups. About two-thirds of Canadian and other North American respondents also immigrated by 1989. Conversely, half or more of respondents from the following regions came to the United States after 1989: Africa (69.7\%), South Asia (62.7\%), East Europe (59.4\%), Central America or Mexico (55.0\%), and South America (51.1\%).

Factors affecting trends in immigration and citizenship are complex, and a lengthy discussion of the political history of world regions, immigration legislation, and immigration policy will not be engaged in here. Very briefly, it can be seen from table 1 that the patterns of immigration by decade vary significantly between geographic groups. As mentioned above, this can be an important consideration for librarians who are working on collection development because established immigrants have different library needs from newly arrived immigrants.

Of the demographic variables examined in previous studies, education level had the strongest impact on whether people used libraries. When the U.S. Census Bureau calculates education level, they do so for adults ages 25 and over, presumably to give time to reasonably assume educational completion. For the adults ages 25 and over in these CPS data, the following was the education distribution at the lowest level:

- $60.0 \%$ of adults from Central America or Mexico completed less than high school education.

- $31.4 \%$ of adults from the Caribbean completed less than high school education.

- $20.2 \%$ or fewer adults from all other geographic groups completed less than high school education.

For groups with the highest education levels, the following was their distribution:

- $80.2 \%$ of adults from South Asia had completed at least some college.

- $70.9 \%$ of adults from Africa had completed at least some college.

- $50 \%$ of adults from all other groups except Central America or Mexico, the Caribbean, and South America had completed at least some college.

Effective public library advertising 


\section{FEATURE}

campaigns for groups with higher education levels might differ from those aimed at groups with lower education levels, as will appropriate collections, programs, and services. Of course, librarians must remember that group data cannot be applied to individuals. For example, while $60 \%$ of immigrant adults from Central America or Mexico did not complete high school, it is not appropriate to assume that any particular patron falls into that category. These numbers are only useful for library planning to best serve the community, not to erroneously peg any individual as having a group characteristic.

Table 2 examines library use in the past month by education level within geographic categories. When all households in the dataset were examined together, there was a direct and linear relationship between education level of household reference person and likelihood that someone in the household used the public library in the past month. The data for all respondent households together were as follows ( $n$ $=43,440$ households):

- For reference persons with less than a high school education, $16.1 \%$ of households used the library in the past month.

- For reference persons with a high school diploma or GED, 24.2\%.

- For reference persons with some college or an associate's degree, $33.9 \%$.

- For reference persons with a bachelor's degree, $41.2 \%$.

- For reference persons with a graduate degree, $46.0 \%$.

As illustrated in Table 2, while this linear relationship was predominately reflected no matter which immigrant group was examined, there were a few interesting differences. Particularly interesting was that at the lowest education level, households of respondents from South America, Southeast Asia, and Central America or Mexico were far more likely to have used the library in the past month than other groups in this education category. In other words, while education has been shown in

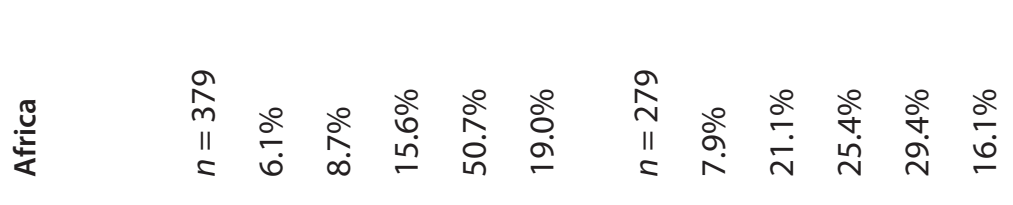

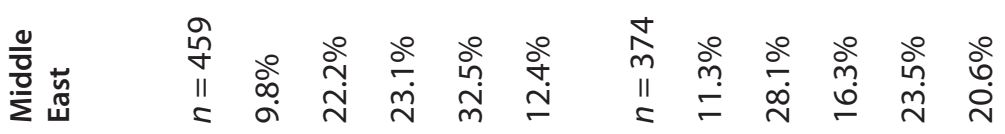

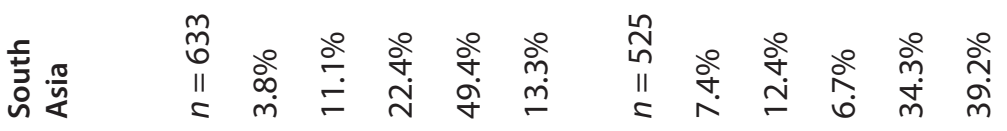

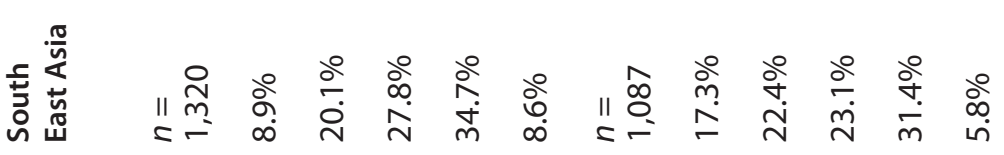

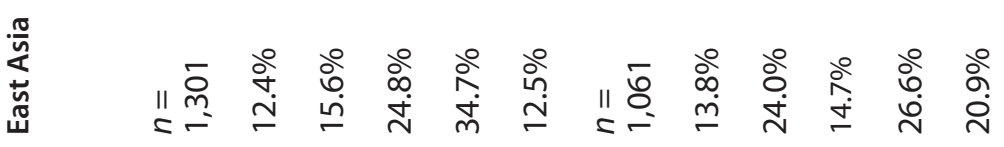

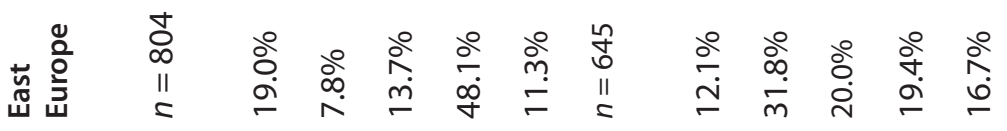

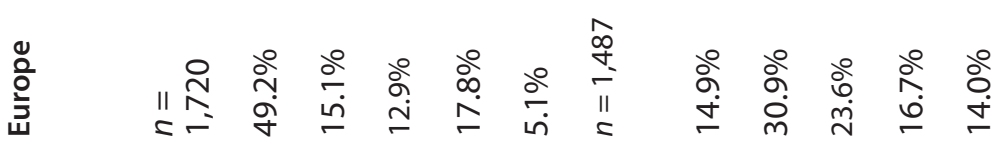

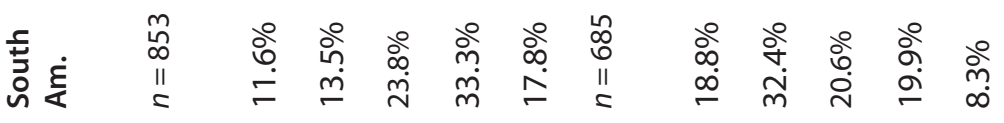

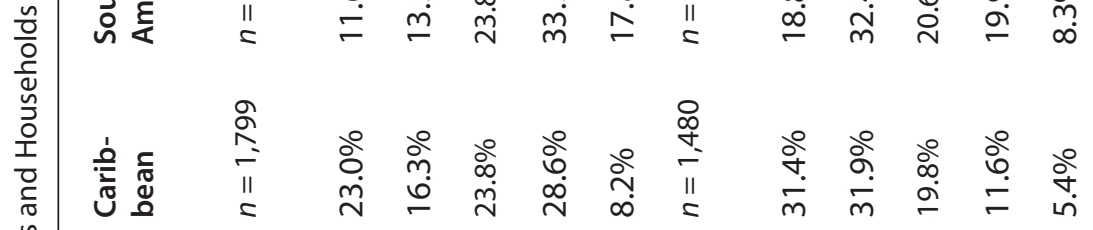

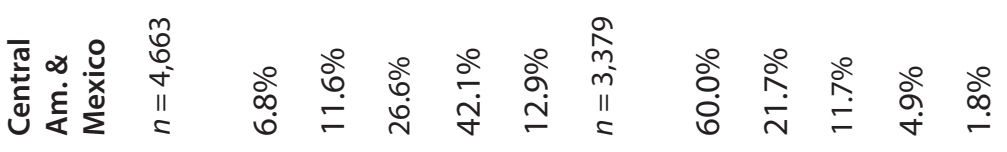

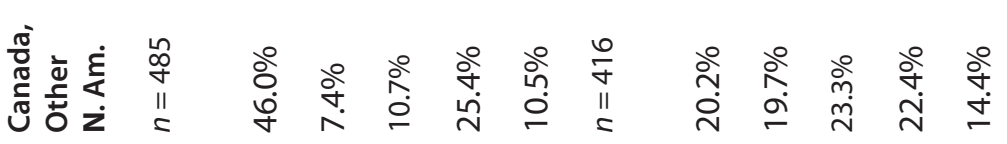

งุ่

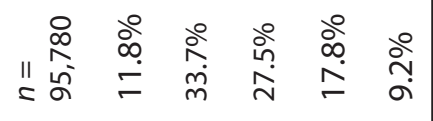

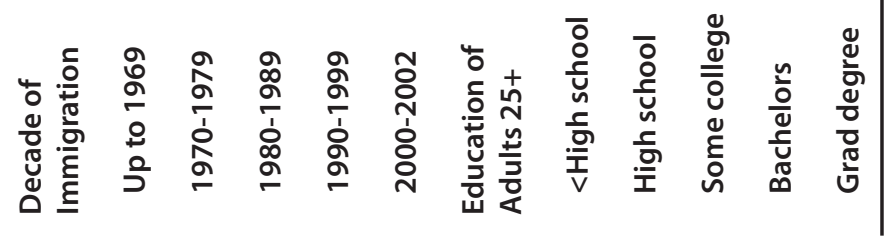


many studies to be the best predictor of library use, this does not apply in the same manner to some immigrant groups. This difference is most likely the result of an intervening variable such as presence of children in the household, family size, or another unidentified variable.

Some other points of interest from the table include the fact that European and East European households were least likely to have used the public library in the past month than other groups in nearly all categories. Between the categories of "some college" and "bachelor's and higher," those with bachelor's degrees or higher from Southeast Asia appear to have used the library less than those who had completed only some college. Geographic regions that did not have enough households to calculate library use within these multiple levels (twenty-five or fewer households in some table cells) were Middle East, Canada or other North America, Africa, and South Asia.

Two previous studies found perceived distance from the public library to be related to library use rates. ${ }^{30}$ Respondents who perceived that they lived closer to the library had higher rates of use than those who thought of the library as farther away. When households of U.S.-born respondents $(n=49,915)$ were analyzed on library use by distance from the library, there was a negative relationship between distance to the library and likelihood of library use in the past month by people in the household. At various distances from the library, rates of public library use in the past month were

- less than 1 mile, 35.9\% of households used the public library;

- 1-2 miles, $32.6 \%$;

- 3-5 miles, $29.6 \%$;

- 6-10 miles, 25.3\%; and

- more than 10 miles, $19.8 \%$.

While nearly $20 \%$ of nonimmigrant households were located six or more miles from a public library, immigrant households were much less likely to be that far away $(6-11 \%)$. This suggests that

Table 2. Used Public Library in Past Month by Education Level of Household Reference Person and Geographic Region of Household Members' Origin (numbers in percentages)

\begin{tabular}{lllll}
\hline $\begin{array}{l}\text { Region of Household } \\
\text { Members' Origin }\end{array}$ & <HS & HS/GED & $\begin{array}{l}\text { Some } \\
\text { College }\end{array}$ & BA+ \\
$\begin{array}{l}\text { South America }(\boldsymbol{n}=\mathbf{2 7 9}) \\
\text { Southeast Asia }(\boldsymbol{n}=\mathbf{4 0 3 )}\end{array}$ & 30.6 & 31.7 & 40.0 & 46.7 \\
Central Am./Mexico $(\boldsymbol{n}=\mathbf{1 , 3 3 0})$ & 25.5 & 29.4 & 42.0 & 39.1 \\
Caribbean $(\boldsymbol{n}=\mathbf{4 6 1 )}$ & 17.5 & 25.3 & 39.3 & 42.5 \\
U.S.-born $(\boldsymbol{n}=\mathbf{4 7 , 3 0 8 )}$ & 14.9 & 24.5 & 34.0 & 43.3 \\
East Asia $(\boldsymbol{n}=\mathbf{4 1 4 )}$ & 11.9 & 24.4 & 32.0 & 45.2 \\
European $(\boldsymbol{n}=\mathbf{4 3 9 )}$ & 11.1 & 16.5 & 28.0 & 35.6 \\
East European $(\boldsymbol{n}=\mathbf{3 0 8})$ & 11.1 & 31.4 & 28.4 & 34.0 \\
\hline
\end{tabular}

immigrants are somewhat more likely than nonimmigrants to live in cities and towns, and less likely to live in rural areas farther from libraries. In this dataset there were not enough immigrant households at the further distances to analyze, so the categories were collapsed to less than a mile, one to two miles, and more than two miles. Immigrant households did not show the same clear correlation between distance from the library and library use shown by nonimmigrant households. Table 3 shows that four immigrant groups had the same pattern as nonimmigrant households of decreased library use with increased distance (Middle Eastern, Caribbean, East European, and Central American or Mexican). Three immigrant groups had the highest use in the middle category, one to two miles from the library (South Asian, African, and East Asian). The remaining four immigrant groups had little to no effect on library use by distance (South American, Southeast Asian, European, and Canadian or other North American). Canada or other North American did show a slight increase of 5 percentage points as distance increased. These data suggest that for immigrant groups, distance of household from public library is not a good predictor of library use.

From the literature review, number of persons in household was found to have no effect on use of public libraries. In table 4 it can be seen that indeed households with more people were much more likely to have used the public library in the past month than households with only one or two people. For all households except those of Canadians or other North Americans, the rates of library use for three or more people were more than double the rates for one to two people. Since this dataset does not have individual-level data, it cannot be determined whether the higher use rate for larger households is a result of more potential library users in the household, the presence of children (also found in the literature to affect library use), or whether individuals in larger households are more likely to use the public library for some other reason. Some immigrant geographic regions are much more likely to have larger households than immigrants from other regions. For example, only $9.5 \%$ of immigrants from Central America or Mexico live in one-person households, while $49.1 \%$ of European immigrants live alone. Households most likely to have only one or two persons were, in descending order, European, Canadian or other North American, East European, U.S.-born, and African (from 77.2 to $59.3 \%$ ). Only $25.2 \%$ of Central American or Mexican households had only one or two people.

In summary for this section, sociodemographic variables can be useful predictors for library use, but their effect does not always apply to immigrant 


\section{FEATURE}

groups in the same way as to households of U.S.-born residents. While education level of household reference person and number of persons in household correlated to likelihood of public library use, geographic origin of household members was an important modifier that affected the use of these variables as predictors.

\section{APPLYING THE RESULTS OF THE STUDY}

A library could apply these data results by using them in conjunction with a community profile to predict library use patterns of different immigrant groups. A community profile can give general figures of the size of the various immigrant groups in a particular community. Size of the immigrant group from the community profile can be combined with likelihood of using the library from this study to give a predictive figure of possible library use by that immigrant group. While South Asians, for example, are more likely to use the library, immigrants from Central America or Mexico might be more likely to have a larger presence in the community, and that may result in more numbers of library users from Central America or Mexico. Identifying the likely patron base is useful to libraries that are planning marketing and outreach efforts. Predicting the information needs of the community base can help the library make good program and materials decisions such as languages in which to purchase materials, literacy levels to target, and other patron special needs.

Library outreach and collection development efforts could take into account factors such as average education levels, years of entry, and household size when planning for different groups. In addition to this, the best way in any given community to find out the library needs of community members is through outreach to community leaders who know their populations and are in touch with their information needs.

This study shows that useful

Table 3. Used Public Library in Past Month by Distance from Library and Geographic Region of Household Members' Origin (numbers in percentages)

Region of Household Members' Origin $\quad<1$ mile $\quad 1-2$ miles $\quad>2$ miles

Library Use Decreased with Distance

$\begin{array}{llll}\text { Middle East }(n=176) & 38.8 & 34.5 & 19.4 \\ \text { U.S-born }(n=49,915) & 35.9 & 32.6 & 27.1 \\ \text { Caribbean }(n=487) & 32.8 & 26.1 & 26.5 \\ \text { East Europe }(n=324) & 32.0 & 29.9 & 23.5 \\ \text { Central America/Mexico }(n=1,485) & 31.6 & 30.7 & 20.5\end{array}$

Library Use Highest in Middle Category

$\begin{array}{llll}\text { South Asia }(n=265) & 41.7 & 50.5 & 41.5 \\ \text { Africa }(n=145) & 22.7 & 37.8 & 26.8 \\ \text { East Asia }(n=451) & 33.3 & 37.6 & 29.0\end{array}$

Distance had Little Impact on Library Use

$\begin{array}{llll}\text { South America }(n=295) & 37.5 & 36.1 & 36.0 \\ \text { Southeast. Asia }(n=423) & 36.4 & 35.2 & 39.9 \\ \text { Europe }(n=450) & 21.8 & 23.1 & 24.2 \\ \text { Canada/other North America }(n=131) & 25.0 & 27.5 & 30.0\end{array}$

Table 4. Used Public Library in Past Month by Number of Persons in Household and Geographic Region of Household Members' Origin (numbers in percentages)

\begin{tabular}{lcc}
\hline Region of Household Members' Origin & $\begin{array}{c}\mathbf{1 - 2} \\
\text { persons }\end{array}$ & $\begin{array}{c}\mathbf{3 +} \\
\text { persons }\end{array}$ \\
South Asia $(n=265)$ & 28.0 & 57.0 \\
Canada/other North American $(n=131)$ & 27.0 & 31.0 \\
U.S.-born $(n=49,915)$ & 22.4 & 47.2 \\
South America $(n=295)$ & 22.4 & 47.1 \\
Southeast Asia $(n=423)$ & 20.5 & 48.2 \\
Africa $(n=145)$ & 18.6 & 44.1 \\
East Asia $(n=451)$ & 18.6 & 48.9 \\
Caribbean $(n=487)$ & 18.3 & 39.4 \\
East Europe $(n=324)$ & 18.2 & 48.7 \\
Middle East $(n=176)$ & 18.1 & 42.4 \\
Europe $(n=450)$ & 17.8 & 41.6 \\
Central America/Mexico $(n=1,485)$ & 14.1 & 32.3 \\
\hline
\end{tabular}

predictive variables for library use by immigrants include region of world from which they immigrated, education level (in this study education level 
of household reference person), and number of persons in the household. Distance from the library was not a good predictor of library use for immigrants.

\section{COMPARISON OF STUDY RESULTS WITH PRIOR STUDIES}

It is difficult to compare the results of this study to the previous studies cited in the literature review because the variables were defined differently between studies. Bala and Adkins stated that 22\% of Latino residents of a Missouri county had used the library in the past 6 months. ${ }^{31}$ Flythe reported $22 \%$ of Hispanic immigrants surveyed in North Carolina had used the public library, but without specifying within a specific period of time. ${ }^{32}$ Rincon and Associates found that $40 \%$ of predominately foreign-born Hispanics in North Carolina had used the library in the past year. ${ }^{33}$ Luevano-Molina reported $50 \%$ of Latino immigrants in Santa Ana, California had used the public library within an unspecified time period. ${ }^{34}$ Metoyer-Duran found $79 \%$ of Latino community leaders had used the library in the past year. Over half of her respondents were U.S. born. ${ }^{35}$ In Trejo's study, 70 out of 71 respondents had used a library at some time in their lives. Her respondents were a mixture of Hispanic immigrants, Mexican Americans, and U.S. whites. ${ }^{36}$ The current study data showed that Caribbean and Central American/Mexican immigrant households used public libraries at basically the same rate, $28.6 \%$ and $27.2 \%$ in the past month. Similar to the study by Rincon and Associates, $40.1 \%$ and $38.2 \%$ had used libraries in the past year. South American immigrant households had a slightly higher, but statistically different, use rate of $36.6 \%$ in the past month and $49.8 \%$ in the past year.

There were two previous studies on Asians' use of U.S. public libraries. Su and Conway reported that $63.3 \%$ of elderly Chinese immigrants in the Los Angeles, California region had used the public library in the past year. ${ }^{37}$
Metoyer-Duran found that Chinese and Korean community information leaders in California used the public library at a rate of $83 \%$ for Chinese and $79 \%$ for Korean in the past year. Most of her Chinese and Korean respondents were immigrants. ${ }^{38}$ In both of these studies the East Asian respondents used the public library at a higher rate than those in the current study which showed East Asian households using the public library at a rate of $33.8 \%$ in the past month and $48.0 \%$ in the past year.

As with previous general studies, these data showed that education level was strongly correlated with public library use. This study also supported the previous assertion that family size, or number in household, affected library use. While Rincon and Associates and Burke found distance to the library to be a useful predictor of library use in other studies, that variable was not a good predictor for immigrant households in this study. ${ }^{39}$

\section{SUGGESTIONS FOR FUTURE RESEARCH}

The most important change suggested for future studies is to gather data for individuals rather than household-level library use. With individual use data, individual demographic data for immigrants such as year of entry, Englishlanguage proficiency, and citizenship status (naturalized versus noncitizen) could be explored as possible contributors to likelihood of using the library. Education level of the individual rather than education level of the household reference person would be a more valuable predictor. Some household variables identified in the literature deserve further study such as presence of school-aged children in the family, household income, and level of English-language reading and speaking skills. While the literature identified several barriers for use by Latino immigrants, this information has not been identified for immigrant groups from other world regions. Similarly, while library materials and programs most useful for Latino immigrants have been studied and some suggestions for Asian patrons have been made, additional studies that gather data on most useful materials for immigrants from other regions could help librarians serving these patrons.

The previous studies on Latino immigrants are on single U.S. geographic regions. Comparative analyses of library needs, for example, of Latino immigrants in California versus those in New York could shed light on regional differences in the United States. Similar studies on other immigrant groups would also be useful. The literature suggests that newly arrived Latino immigrants need more information on practical issues such as finding jobs, housing, learning English, and learning computer skills. Do immigrants from other regions display these same needs? While this study examined the tendency of immigrants to use the public library, future studies need to examine to what use immigrant library patrons put their libraries.

While this study contained only quantitative data, qualitative studies could enrich the knowledge base by giving immigrants a voice to articulate for themselves the barriers they perceive, the information needs they want the library to fill, and their perceptions of the public library. The literature identified several means of reaching immigrants such as focus groups at community centers, door to door interviewing, and street-corner canvassing.

In conclusion, the picture that library professionals have of immigrants' use of public libraries is incomplete. While additional studies of the library use of immigrants from Latin America and Asia would be useful, there is a particular need for studies of immigrants from other world regions.

\section{References}

1. 2003 Yearbook of Immigration Statistics (Washington, D.C.: U.S. Department of Homeland Security, Office of Immigration Statistics, 2004), www.uscis.gov/graphics/ shared/statistics/yearbook/2003/2003 Yearbook.pdf (accessed Aug. 23, 2006).

2. Campbell Gibson and Kay Jung, Historical Census Statistics of the Foreign-born Population of the United States: 1850-2000: Working Paper No. 81 (U.S. Census Bureau, 


\section{FEATURE}

Population Division, 2006), www.census gov/population/www/documentation/ twps0081/twps0081.pdf (accessed July $25,2008)$

3. The Foreign-born Population in 2004 (U.S. Census Bureau, Population Profile of the United States: Dynamic Version), www .census.gov/population/www/popprofile/files/dynamic/ForeignBorn.pdf (accessed July 25, 2008).

4. Public Library Services to New Americans: Speeding Transitions to Learning, Work and Life in the U.S. (Evanston, Ill.: Urban Libraries Council, 2003): 4.

5. Wayne A. Wiegand, An Active Instrument for Propaganda: The American Public Library During World War I (Westport, Conn.: Greenwood, 1989): 117.

6. Lawrence J. White, The Public Library in the 1980s: The Problems of Choice (Lexington, Mass.: Lexington Books, 1983); Douglas Zweizig and Brenda Dervin, "Public Library Use, Users, Uses: Advances in Knowledge of the Characteristics and Needs of the Adult Clientele of American Public Libraries," in Advances in Librarianship, ed. Melvin J. Voigt and Michael H. Harris (New York: Academic Pr., 1977): 231-55.

7. Zweizig and Dervin, "Public Library Use, Users, Uses," 236.

8. Ibid., 238-40.

9. Judith Payne, Public Libraries Face California's Ethnic and Racial Diversity (Santa Monica, Calif.: Rand, 1988).

10. Carol L. Kronus, "Patterns of Adult Library Use: A Regression and Path Analysis," Adult Education 23 (Winter 1973): 115-31.

11. Zweizig and Dervin, "Public Library Use, Users, Uses."

12. Amado M. Padilla, Public Library Services for Immigrant Populations in California (Sacramento, Calif.: California State Library Foundation, 1991).

13. Susan Luevano-Molina, "Ethnographic Perspectives on Trans-national Mexican Immigrant Library Users," in Library Services to Latinos: An Anthology, ed. Salvadore Guerena (Jefferson, N.C.: McFarland, 2000): 169-80.

14. Susan Luevano-Molina, "Mexican/Latino Immigrants and the Santa Ana Public Library: An Urban Ethnography," in
Immigrant Politics and the Public Library, ed. Susan Luevano-Molina (Westport, Conn.: Greenwood, 2001): 43-63.

15. Ninfa Almance Trejo, "Impact of Proposition 187 on Public Libraries and Elementary Education in Tucson, Arizona," in Immigrant Politics and the Public Library, ed. Susan Luevano-Molina (Westport, Conn.: Greenwood, 2001): 89-100.

16. Rincon and Associates, Survey of Library Needs for North Carolina Hispanics (2000) http://statelibrary.dcr.state.nc.us/hispanic/nclibrpt.pdf (accessed Oct. 5, 2006).

17. Frances H. Flythe, Identification of the Information Needs of Newly Arrived Hispanic/Latino Immigrants in Durham County, North Carolina, and How the Public Library May Address Those Need (master's thesis, Chapel Hill, N.C.: University of North Carolina, 2001), http://ils.unc.edu/MSpapers/2666.pdf (accessed Oct. 5, 2006).

18. Beth Bala and Denice Adkins, "Library and Information Needs of Latinos in Dunklin County, Missouri," Public Libraries 43 (Mar./Apr. 2004): 119-22.

19. Payne, Public Libraries Face California's Ethnic and Racial Diversity; Padilla, Public Library Services for Immigrant Populations in California; Jon Sudell, "Library Service to Hispanic Immigrants of Forsyth County, North Carolina: A Community Collaboration," in Library Services to Latinos: An Anthology, ed. Salvadore Guerena (Jefferson, N.C.: McFarland, 2000): 143-68; Rincon and Associates, Survey of Library Needs for North Carolina Hispanics; Bala and Adkins, "Library and Information Needs of Latinos in Dunklin County, Missouri."

20. Sherry Shiuan Su and Charles W. Conaway, "Information and a Forgotten Minority: Elderly Chinese Immigrants," Library and Information Science Research 17 (Winter 1995): 69-86.

21. Padilla, Public Library Services for Immigrant Populations in California.

22. Cheryl Metoyer-Duran, Gatekeepers in Ethnolinguistic Communities (Norwood, N.J.: Ablex, 1993).

23. Public Library Services to New Americans.

24. Louis Escobar-Matute, Joa-Ming Huang, and Sara Martinez, "Language Barriers: How Do You Handle Them?" (panel presented at the annual meeting of the Oklahoma Library Association, Oklahoma City, Apr. 4, 2007).

25. Zweizig and Dervin, "Public Library Use, Users, Uses"; Payne, Public Libraries Face California's Ethnic and Racial Diversity; Kronus, "Patterns of Adult Library Use."

26. Susan K. Burke, "Use of Public Libraries by Native Americans," Library Quarterly 77 (Oct. 2007), 429-61; Kronus, "Patterns of Adult Library Use."

27. Rincon and Associates, Survey of Library Needs for North Carolina Hispanics.

28. Scott Nicholson, "Understanding Communities of Library Users through Information Seeking and Retrieval in Context," forthcoming.

29. U.S. Dept. of Commerce, Bureau of the Census, Current Population Survey, October 2002: School Enrollment/Library Use [Computer file]. ICPSR release (Washington, D.C.: U.S. Dept. of Commerce, Bureau of the Census [producer], 2004; Ann Arbor, Mich.: Inter-university Consortium for Political and Social Research [distributor]).

30. Burke, "Use of Public Libraries by Native Americans"; Rincon and Associates, Survey of Library Needs for North Carolina Hispanics.

31. Bala and Adkins, "Library and Information Needs of Latinos in Dunklin County, Missouri."

32. Flythe, Identification of the Information Needs of Newly Arrived Hispanic/Latino Immigrants.

33. Rincon and Associates, Survey of Library Needs for North Carolina Hispanics.

34. Luevano-Molina, "Ethnographic Perspectives on Trans-national Mexican Immigrant Library Users."

35. Metoyer-Duran, Gatekeepers in Ethnolinguistic Communities.

36. Trejo, "Impact of Proposition 187."

37. Su and Conaway, "Information and a Forgotten Minority."

38. Metoyer-Duran, Gatekeepers in Ethnolinguistic Communities.

39. Burke, "Use of Public Libraries by Native Americans"; Rincon and Associates, Survey of Library Needs for North Carolina Hispanics. 